\title{
Neuromyelitis optica: phenotypic characteristics in a Brazilian case series
}

\author{
Neuromielite óptica: características fenotípicas em uma série de casos brasileiros \\ Maria Cristina Del Negro', Patricia Beatriz Christino Marinho', Regina Maria Papais-Alvarenga²
}

\begin{abstract}
The definition of neuromyelitis optica (NMO) is still evolving. In 2015, the International Panel for NMO Diagnosis was convened to develop revised diagnostic criteria. There have been few studies on NMO in the Brazilian population. Objective: To describe the characteristics of 34 Brazilian NMO patients. To evaluate the contribution of the 2015 criteria to the diagnosis of NMO spectrum disorders (NMOSD) in 40 patients with longitudinal extensive transverse myelitis (LEMT). Methods: This is a retrospective, descriptive and analytic study. Results: Among NMO patients, there was a predominance of women, with onset in the fourth decade of life, and AQP4-IgG seropositivity in 73.5\%. The diagnosis of NMOSD was established in 37.5\% of LETM patients according to AQP4-IgG positivity and in 5\% of LETM patients if the AQP4-IgG result was unknown. Conclusions: The characteristics of this series are similar to those of other Western populations. The AQP4-IgG testing assists in the diagnosis of NMOSD.
\end{abstract}

Keywords: neuromyelitis optica; epidemiology; cross-sectional studies. enzyme-linked immunosorbent assay.

\section{RESUMO}

Neuromielite óptica (NMO) é um conceito em evolução. Em 2015, o Painel Internacional para o diagnóstico de NMO apresentou novos critérios diagnósticos. Poucos são os estudos em NMO na população brasileira. Objetivos: Descrever as características de 34 casos brasileiros de NMO. Avaliar a contribuição dos critérios de 2015 para o diagnóstico de desordens do espectro NMO em 40 pacientes com mielite transversa longitudinal extensa (MTLE). Métodos: Estudo retrospectivo, descritivo e analítico. Resultados: Predomínio do sexo feminino, início na quarta década e anticorpo anti-AQP4 positivo em 73,5\% dos casos de NMO. Diagnóstico de desordem do espectro NMO estabelecido em $37.5 \%$ dos casos de MTLE com positividade do anticorpo anti-AQP4 e em $5 \%$ se o resultado sorológico fosse desconhecido. Conclusões: Esta série de casos de NMO tem características semelhantes às de outras séries ocidentais. A pesquisa do anticorpo anti-AQP4 é relevante para o diagnóstico das desordens do espectro da NMO.

Palavras-chave: neuromielite óptica; epidemiologia; estudo transversal, ensaio enzimático.

The association between optic neuritis $(\mathrm{ON})$ and transverse myelitis (TM) has been known since the $19^{\text {th }}$ century. The term neuromyelitis optica (NMO) was first used in 1894 by Eugène Devic when describing the case of a female patient with bilateral ON and TM with severe functional deficits and subsequent death ${ }^{1}$. First considered a variant of multiple sclerosis, NMO is currently regarded as a distinct disease, because it has clinical manifestations and radiological and pathological features that differ from multiple sclerosis ${ }^{2}$.

The first diagnostic criteria for NMO were formulated in 1999 and intended to distinguish NMO from multiple sclerosis. At that time, exclusive clinical dysfunction of the optic nerves and spinal cord was considered mandatory for diagnosis. Suggestive findings in diagnostic tests and clinical characteristics emphasizing the severity of disease were considered major and minor criteria, respectively3.

The discovery of a highly specific antibody for NMO in $2004^{4}$ and of its target antigen, aquaporin 4 (AQP4) in the following year ${ }^{5}$, allowed the recognition of limited forms of the disease and the characterization of dysfunction at other sites in the central nervous system. These developments led to a revision of the diagnostic criteria for NMO in $2006^{6}$.

In 2007, the term NMO spectrum disorders (NMOSD) was introduced to extend to AQP4-IgG-seropositive patients with limited forms of NMO who were at high risk for future attacks?

The refinement of the list of non-opticospinal disease characteristics and the presence of AQP4-IgG-seronegative patients or those with unknown serostatus have rendered the 2006 criteria inadequate for contemporary practice and

${ }^{1}$ Rede Sarah de Hospitais de Reabilitação, Serviço de Neurologia, Brasília DF, Brasil;

¿Universidade Federal do Estado do Rio de Janeiro, Hospital Universitário Gaffrée \& Guinle, Serviço de Neurologia, Rio de Janeiro RJ, Brasil.

Correspondence: Maria Cristina Del Negro. SMHS Quadra 301/Bloco A; 70335-910 Brasília DF, Brasil; E-mail: del.negro@uol.com.br

Conflict of interest: There is no conflict of interest to declare.

Received 10 June 2015; Received in final form 02 February 2016; Accepted 17 October 2016. 
research. The term NMOSD has also been used variably in the literature and requires clarification. In 2015, the International Panel for NMO Diagnosis was convened to develop revised diagnostic criteria and to define the nomenclature. The panel recommends prospective validation of the criteria ${ }^{8}$.

There appear to be differences among NMO patients according to serostatus. Some studies suggest that AQP4IgG-seronegative patients are younger, less frequently female, and less likely to relapse 9 .

In this study, we describe the demographic, clinical, and paraclinical characteristics of a Brazilian series of patients with NMO, and search for differences as a function of serostatus. We also evaluate the contribution of the 2015 criteria to the diagnosis of NMOSD in a series of patients with longitudinal extensive transverse myelitis (LETM).

\section{METHODS}

This is a retrospective, descriptive and analytic study.

Patients of any age diagnosed with NMO, according to the 2006 Wingerchuk et al. ${ }^{6}$ criteria, or with LETM (three or more contiguous spinal segments, without other known etiology), subjected to AQP4-IgG testing at the Brasilia unit of the Sarah Network of Rehabilitation Hospitals from November 2009 to July 2012, were included.

The AQP4-IgG testing was performed using a commercial ELISA-R kit (recombinant human AQP4, M1 isoform), with a cutoff of $5 \mathrm{U} / \mathrm{ml}$.

The variables were gender, age at initial event, skin color (white/non-white), initial clinical event (isolated TM, isolated $\mathrm{ON}$, simultaneous TM and $\mathrm{ON}$, and brainstem syndrome), time from first relapse to first appointment, time interval between index events (ON and TM), duration of the disease, presence and total number of recurrences, score on the Expanded Disability Status Scale at last assessment, associated immune disease, AQP4-IgG serostatus, findings on spine magnetic resonance imaging (MRI) (the presence of extensive spinal cord injury, central lesions, and affected spinal cord segments), findings on brain MRI (normal, nonspecific lesions, or typical NMO lesions according to $\mathrm{Kim}^{10}$ ), the presence of other autoantibodies (antinuclear antibody, anti-Sjögren's-syndrome-related antigen $\mathrm{A}$, and anticardiolipin), whether AQP4-IgG testing was performed during an attack, and whether testing occurred before or after immunosuppression.

For the statistical analyses, the variables are expressed as means \pm standard deviations and were compared between groups using Student's t-test or the Mann-Whitney test. For variables expressed as frequencies, the groups were compared using the chi-square test or Fisher's exact test. P-values $<0.05$ were considered significant.

The study was approved by the research ethics committee of the Sarah Network of Rehabilitation Hospitals.

\section{RESULTS}

A total of 34 patients diagnosed with NMO according to the Wingerchuk et al. ${ }^{6} 2006$ criteria were identified. Most patients were female (7.5 females: 1 male), and the average disease onset had occurred by the fourth decade of life (34.6 \pm 17.2 years of age; range: $4-68$ years of age). Six patients exhibited late disease onset, after 50 years of age, and five patients experienced onset before 16 years of age. Approximately $45 \%$ of the patients were non-white. The average time from the first attack to the first appointment was $23.7 \pm 26,5$ months (0-108 months). The initial clinical event was ON or TM in approximately $60 \%$ of the patients; simultaneous ON and TM (interval of up to one month between each event) occurred in $23.5 \%$ of the patients; and brainstem syndrome, mainly uncontrollable vomiting and persistent hiccups, was observed in $17.6 \%$ of the patients. Recovery after the initial clinical event was complete in slightly more than $25 \%$ of the patients and absent in almost $20 \%$. The time between the index events was highly variable (mean: $14.7 \pm 29.5$ months; range: $0-108$ months). The mean duration of disease was $8.1 \pm 5.5$ years, and $73.5 \%$ of the patients were classified as recurrent NMO. In $73.5 \%$ of the patients, AQP4-IgG seropositivity was detected by ELISA. Spinal cord lesions were central in approximately $90 \%$ of the patients, and the cervicothoracic segment was the most often affected site. Brain MRI examinations exhibited typical NMO findings in $26.5 \%$ of the patients. An association with another autoimmune disease was found in approximately $30 \%$ of the patients (an association with thyroiditis was observed in $62.5 \%$ of these patients). Other autoantibodies were detected in more than $50 \%$ of patients and, in most instances, corresponded to ANA in low titers.

The average time from the last attack to the serologic test was $28.4 \pm 34,6$ months (0-108 months). Only six patients (18\%) had AQP4-IgG testing less than one month after relapse. Twenty-four patients (70\%) were on immunosuppressive drug treatment (prednisone and azathioprine 12 patients, azathioprine 12 patients) when serological testing was performed. Neither factor significantly affected the results of AQP4-IgG testing (Table 1). Thirty-three patients (97\%) remained free of attacks during immunosuppressive therapy.

In a comparison of recurrent and monophasic NMO, the latter showed a greater prevalence of isolated TM and of simultaneous ON and TM as the initial clinical event, and of other autoimmune diseases (Table 2).

By comparing the patients according to their serostatus, we found a greater proportion of women and non-white patients in the AQP4-IgG seropositive group and greater functional deficits, defined as higher Expanded Disability Status Scale scores, in the AQP4-IgG seronegative group. However, none of these findings were statistically significant (Table 3). 
Forty patients were diagnosed with LETM (25 monophasic LETM, 15 recurrent LETM). Thirteen(32.5\%) were AQP4-IgG seropositive and, as a result, defined as NMOSD. Only two recurrent
NMO patients had brainstem syndrome and neuroimaging suggestive of NMOSD, matching the diagnosis of NMOSD according to the 2015 criteria, but both were AQP4-IgG seropositive.

Table 1. Characteristics of the patients when AQP4-IgG was performed.

\begin{tabular}{|c|c|c|c|c|}
\hline Characteristics n(\%) & Total & AQP4-IgG+ & AQP4-IgG- & $p$-value \\
\hline Time from attack & & & & 1.0000 \\
\hline$>1$ month & $28(82.4)$ & $20(80.0)$ & $8(88.9)$ & - \\
\hline$\leq 1$ month & $6(17.6)$ & $5(20.0)$ & $1(11.1)$ & - \\
\hline Immunosuppressive drugs & & & & 0.6921 \\
\hline No & $10(29.4)$ & $8(32.0)$ & $2(22.2)$ & - \\
\hline Yes & $24(70.6)$ & $17(68.0)$ & $7(77.8)$ & - \\
\hline
\end{tabular}

p-value according to Fisher's test or Chi-square test.

Table 2. Demographic, clinical and paraclinical characteristics of the patients with NMO.n(\%)

\begin{tabular}{|c|c|c|c|c|}
\hline Characteristics $\mathrm{n}(\%)$ & NMO & rNMO & mNMO & $p$-value \\
\hline Gender & & & & 1.000 \\
\hline Female & $30(88.2)$ & $22(88.0)$ & $8(88.9)$ & - \\
\hline Male & $4(11.8)$ & $3(12.0)$ & $1(11.1)$ & - \\
\hline Age of onset & $34.6 \pm 17.2$ & $36.3 \pm 16.6$ & $30.1 \pm 19.1$ & 0.489 \\
\hline Skin color & & & & 1.000 \\
\hline White & $15(55.6)$ & $11(55.0)$ & $4(57.1)$ & - \\
\hline Non-white & $12(44.4)$ & $9(45.0)$ & $3(42.9)$ & - \\
\hline Unknown & 7 & 5 & 2 & - \\
\hline Initial clinical event & & & & 0.080 \\
\hline ON & $10(29.4)$ & $9(36.0)$ & $1(11.1)$ & - \\
\hline $\mathrm{TM}$ & $10(29.4)$ & $6(24.0)$ & $4(44.4)$ & - \\
\hline Simultaneous ON and TM & $8(23.5)$ & $4(16.0)$ & $4(44.4)$ & - \\
\hline Brainstem syndrome & $6(17.6)$ & $6(24.0)$ & $0(0.00)$ & - \\
\hline Interval between events months & $14.7 \pm 29.5$ & $12.5 \pm 27.0$ & $20.3 \pm 36.3$ & 0.621 \\
\hline Autoimmune comorbidities & & & & 0.034 \\
\hline No & $25(73.5)$ & $21(84.0)$ & $4(44.4)$ & - \\
\hline Yes & $9(26.5)$ & $4(16.0)$ & $5(55.6)$ & - \\
\hline Initial event recovery & & & & 1.000 \\
\hline Absent & $7(20.6)$ & $5(20.0)$ & $2(22.2)$ & - \\
\hline Partial & $19(55.9)$ & $14(56.0)$ & $5(55.6)$ & - \\
\hline Complete & $8(23.5)$ & $6(24.0)$ & $2(22.2)$ & - \\
\hline Disease duration - years & $8.1 \pm 5.5$ & $8.5 \pm 5.6$ & $6.9 \pm 5.4$ & 0.376 \\
\hline EDSS $^{*}$ & $6.5 \pm 2.5$ & $6.0 \pm 2.5$ & $6.5 \pm 3.0$ & 0.565 \\
\hline AQP4-lgG+ & $25(73.5)$ & $19(76.0)$ & $6(66.7)$ & 0.670 \\
\hline Affected spinal cord segment & & & & 0.262 \\
\hline Cervical & $5(14.7)$ & $5(20.0)$ & $0(0.00)$ & - \\
\hline Cervicothoracic & $19(55.9)$ & $13(52.0)$ & $6(66.7)$ & - \\
\hline Thoracic & $7(20.6)$ & $4(16.0)$ & $3(33.3)$ & - \\
\hline Entire spinal cord & $3(9.0)$ & $3(12.0)$ & $0(0.00)$ & - \\
\hline Central spinal cord lesion & $30(88.2)$ & $22(88.0)$ & 8 (88.9) & 1.000 \\
\hline Brain MRI & & & & 0.678 \\
\hline Normal & $7(20.6)$ & $6(24.0)$ & $1(11.2)$ & - \\
\hline Typical NMO findings & $9(26.5)$ & $7(28.0)$ & $2(22.2)$ & - \\
\hline Unspecific findings & $18(52.9)$ & $12(48.0)$ & $6(66.7)$ & - \\
\hline Other autoantibodies & & & & - \\
\hline ANA & $16(47.1)$ & $11(44.0)$ & $5(55.6)$ & 0.703 \\
\hline Anti-SSA & $1(3.2)$ & $1(4.2)$ & $0(0.0)$ & 1.000 \\
\hline Anticardiolipin & $7(21.9)$ & $6(26.1)$ & $1(11.2)$ & 0.640 \\
\hline
\end{tabular}

NMO: neuromyelitis optica; r: recurrent; m: monophasic; ON: optic neuritis; TM: transverse myelitis; EDSS: expanded disability status scale; AQP4: aquaporin 4; MRI: magnetic resonance imaging; ANA: antinuclear antibody; SSA: anti-Sjögren's-syndrome-related antigen A. *Values expressed as the median; \pm interquartile range. 
Table 3. Demographic, clinical and paraclinical characteristics by serological status.

\begin{tabular}{|c|c|c|c|}
\hline Characteristics $\mathrm{n}(\%)$ & AQP4-IgG+ & AQP4-IgG - & $p$-value \\
\hline Gender & & & 0.281 \\
\hline Female & $23(92.0)$ & $7(77.8)$ & \\
\hline Male & $2(8.0)$ & $2(2.2)$ & \\
\hline Age of onset & $33.8 \pm 17.3$ & $37.0 \pm 17.7$ & 0.640 \\
\hline Skin color & & & 0.219 \\
\hline White & $9(45.0)$ & $6(85.7)$ & \\
\hline Non-white & $11(50.0)$ & $1(14.3)$ & \\
\hline Unknown & 5 & 2 & \\
\hline Initial clinical event & & & 0.901 \\
\hline ON & $7(28.0)$ & $3(33.3)$ & \\
\hline $\mathrm{TM}$ & $9(36.0)$ & $2(22.2)$ & \\
\hline Simultaneous ON and TM & $5(20.0)$ & $3(33.3)$ & \\
\hline Brainstem syndrome & $4(16.0)$ & $1(11.1)$ & \\
\hline Autoimmune comorbidities & & & 0.670 \\
\hline No & $19(76.0)$ & $6(66.7)$ & \\
\hline Yes & $6(24.0)$ & 3 (33.3) & \\
\hline Initial event recovery & & & 0.769 \\
\hline Absent & $5(20.0)$ & $1(11.1)$ & \\
\hline Partial & $13(52.0)$ & $6(66.7)$ & \\
\hline Complete & $7(28.0)$ & $2(22.2)$ & \\
\hline Recurrences & & & 0.425 \\
\hline No & $6(24.0)$ & 3 (33.3) & \\
\hline Yes & $19(76.0)$ & $6(66.7)$ & \\
\hline Disease duration - years & $8.0 \pm 5.7$ & $7.9 \pm 5.6$ & 0.960 \\
\hline EDSS $^{*}$ & $6.0 \pm 4.0$ & $8.0 \pm 1.5$ & 0.081 \\
\hline Central spinal cord lesion & $23(92.0)$ & $7(77.8)$ & 0.281 \\
\hline Affected spinal cord segments & & & 0.320 \\
\hline Cervical & $5(20.0)$ & $0(0.0)$ & \\
\hline Cervicothoracic & $14(56.0)$ & $5(55.6)$ & \\
\hline Entire spinal cord & $2(8.0)$ & $1(11.1)$ & \\
\hline Thoracic & $4(16.0)$ & $3(33.3)$ & \\
\hline Brain MRI & & & 1.000 \\
\hline Normal & $5(20.0)$ & $2(22.2)$ & \\
\hline Typical NMO findings & $6(24.0)$ & $2(22.2)$ & \\
\hline Nonspecific findings & $14(56.0)$ & $5(55.6)$ & \\
\hline Other autoantibodies & & & 0.462 \\
\hline Present & $15(60.0)$ & $4(44.4)$ & \\
\hline Absent & $10(40.0)$ & $5(55.6)$ & \\
\hline
\end{tabular}

\section{DISCUSSION}

The definition of NMO is still evolving. The International Panel for NMO Diagnosis affirmed the decision to unify the terms $\mathrm{NMO}$ and $\mathrm{NMOSD}^{8}$. The index events required for diagnosis, now termed core clinical characteristics, include ON, TM, area postrema syndrome (episode of otherwise unexplained hiccups or nausea and vomiting), acute brainstem syndrome, symptomatic narcolepsy or acute diencephalic clinical syndrome with NMOSD-typical diencephalic MRI lesions, and symptomatic cerebral syndrome with NMOSD-typical brain lesions ${ }^{8}$. Bilateral and/or recurrent $\mathrm{ON}$, poor recovery of visual acuity, lesions extending over half the optic nerve length or involving the optic chiasm, and the absence of visual evoked potentials are indicative of NMOSD ${ }^{11}$. Painful tonic spasms, sensory level, bilateral motor impairment, persistent sphincter dysfunction, extensive and central spinal cord lesions on MRI performed within the first weeks after the onset of symptoms, spinal cord cavitation and late atrophy are common findings in NMOSD ${ }^{3,6}$.

The demographic characteristics of NMO patients are reinforced by each successive published study. Neuromyelitis optica patients are predominantly female, with a ratio higher than that of multiple sclerosis; the average age at onset is older, usually by the end of the fourth decade of life; and the prevalence of non-white patients is higher than that of other demyelinating diseases ${ }^{12,13,14,15,16,17,18}$. These demographic characteristics were also present in the current Brazilian NMO 
case series and were similar to those reported for other case series in the country ${ }^{19,20,21,22}$. The exceptions include a younger age at onset in the Adoni et al. ${ }^{21}$ series, in which only patients with recurrent NMO were analyzed, and lower female-to-male ratios in the Alves-Leon et al. ${ }^{20}$ and Bichuetti et al. ${ }^{22}$ series (Table 4).

All NMO patients in our series exhibited extensive longitudinal spinal cord lesions in at least one spinal MRI, and none had imaging features suggestive of multiple sclerosis. Therefore, AQP4-IgG seropositivity was not mandatory to establish the diagnosis of $\mathrm{NMO}^{6,8}$.

The most common initial events were isolated ON or isolated TM, recovery was generally partial or absent, the average time to the second core event was longer than one year, and immunosuppressive therapy appeared highly effective at reducing relapses. These findings reinforce the relevance of early diagnosis and early onset of immunosuppressive therapy. The AQP4-IgG testing may help the diagnosis of NMOSD. Diagnostic requirements are more stringent for patients in whom AQP4-IgG is not detected or for whom testing is unavailable ${ }^{8}$. In this series of patients with LETM, the diagnosis of NMOSD was established in 37.5\%, based on AQP4-IgG positivity. If the AQP4-IgG result was unknown, only $5 \%$ would meet the diagnosis, according to 2015 criteria.

In the present case series, AQP4-IgG seropositivity was similar to that reported by Lennon et al. ${ }^{4}$ (73\%) and was higher than that found by Adoni et al. ${ }^{23}$ in Brazilian patients with recurrent NMO; both studies used the IF method.

An AQP4-IgG seropositivity by the ELISA method reported for other Western populations varies from 60 to $76 \% \%^{9,24,25}$. The use of the isotype AQP4 M23 increases the sensitivity of this method $^{26,27}$. Currently, cell-based assays are strongly recommended $^{8,25}$, but the expertise and resources required to perform those assays preclude their use in small-scale clinical diagnostic laboratories. A previous study affirms that commercially available kit assays (ELISA-R and CBA-E) are both sensitive and specific for AQP4-IgG detection, and their relative simplicity to perform allows small-scale laboratories to offer sensitive and specific AQP4-IgG testing ${ }^{25}$.

We did not find any significant difference among NMO patients according to their serological status. The proportions of women and of people of African descent were higher in the AQP4-IgG seropositive group. The small numbers of seropositive and seronegative patients may account for the lack of significant differences between the groups.

In our series, an association with other autoimmune diseases was more frequent among the monophasic patients. Isolated TM or simultaneous ON and TM were more prevalent as initial events in that group, although this difference was non-significant. Once again, the small number of recurrent and monophasic patients reduced the statistical power of the sample.

Table 4. Characteristic of Brazilian NMO case series.

\begin{tabular}{|c|c|c|c|c|c|}
\hline \multirow{2}{*}{ Variable } & Papais-Alvarenga & Alves-Leon & Adoni & Bichuetti & Del Negro \\
\hline & 2002 & 2008 & 2008 & 2009 & 2014 \\
\hline Number of cases & 24 & 28 & 28 & 41 & 34 \\
\hline Study period & $1995-2001$ & $2003-2005$ & NR & $1994-2007$ & 2009-2012 \\
\hline female:male ratio & 05:01 & 03:01 & 08:01 & $2.4: 1$ & 7.5: 1 \\
\hline Age of onset & 32.8 & 29.3 & 26 & 32.6 & 34.6 \\
\hline Disease duration years & 7.7 & 12.3 & 7 & 7.4 & 8.0 \\
\hline Final EDSS & 6 & 3.2 & 5.5 & 5.2 & 6.5 \\
\hline \multicolumn{6}{|l|}{ Initial event \% } \\
\hline ON & 33.3 & 46.4 & 61 & 34 & 29.4 \\
\hline Myelitis & 37.5 & 28.6 & 39 & 42 & 29.4 \\
\hline $\mathrm{ON}+$ myelitis & 29.2 & 25.0 & 0 & 24 & 23.5 \\
\hline AQP4-IgG+ \% & Not tested & NR & 64.3 & $41(n=17)$ & 73.53 \\
\hline Other Al disease \% & 12.5 & NR & 21 & 7 & 26.5 \\
\hline Other autoAb \% & NR & NR & 46 & 34 & 55.9 \\
\hline \multicolumn{6}{|l|}{ Affected segments \% } \\
\hline Cervical & NR & NR & 36 & NR & 14.7 \\
\hline Cervicothoracic & NR & NR & 46.4 & NR & 55.9 \\
\hline Thoracic & NR & NR & 17.6 & NR & 17.6 \\
\hline Entire spinal cord & NR & NR & NR & NR & 8.8 \\
\hline Abnormal brain MRI \% & 38 & NR & NR & 59 & 79.4 \\
\hline \multicolumn{6}{|l|}{ CSF $\%$} \\
\hline Normal & 52 & NR & NR & NR & 44.1 \\
\hline Pleocytosis & 37.5 & NR & NR & $10 *$ & 32.3 \\
\hline Increased protein & 45.8 & $N R$ & $N R$ & NR & 38.7 \\
\hline $\mathrm{OB}$ & 21 & NR & NR & 0 & 3.4 \\
\hline
\end{tabular}

NMO: neuromyelitis optica; EDSS: expanded disability status scale; Al: autoimmune; NR: non-recorded; ON: optic neuritis; AQP4: aquaporin 4; Ab: antibody; MRI: magnetic resonance imaging; CSF: cerebrospinal fluid; OB: oligoclonal bands. * more than 50 leukocytes/field 
Because it is a rare disease, multicenter studies and meta-analyses are needed to achieve better epidemiological characterization of NMO and NMOSD. The establishment of databases, such as NEMOS ${ }^{17}$ and NMO-DBr ${ }^{28}$, is fundamental.

In conclusion, the characteristics exhibited by the present series of Brazilian patients with NMO reinforce those reported for other Western populations. The ELISA-R method exhibited satisfactory sensitivity for the detection of AQP4-IgG. The most common initial events included limited forms of the disease, which emphasizes the relevance of AQP4-IgG testing in such patients. No statistically-significant difference was found between patients as a function of their serological status, but the small sample size may have led to this result.

\section{References}

1. Jarius $S$, Wildemann B. The history of neuromyelitis optica.J Neuroinflammation. 2013;10(1):8. http://doi.org/10.1186/1742-2094-10-8

2. O'Riordan JI, Gallagher HL, Thompson AJ, Howard RS, Kingsley DP, Thompson EJ et al. Clinical, CSF, and MRI findings in Devic's neuromyelitis optica.J Neurol Neurosurg Psychiatry. 1996;60(4):382-7. http://doi.org/10.1136/jnnp.60.4.382

3. Wingerchuk DM, Hogancamp WF, O'Brien PC, Weinshenker BG. The clinical course of neuromyelitis optica (Devic's syndrome). Neurology. 1999;53(5):1107-14. http://doi.org/10.1212/WNL.53.5.1107

4. Lennon VA, Wingerchuk DM, Kryzer TJ, Pittock SJ, Lucchinetti CF, Fujihara K et al. A serum autoantibody marker of neuromyelitis optica: distinction from multiple sclerosis. Lancet. 2004;364(9451):2106-12. http://doi.org/10.1016/S0140-6736(04)17551-X

5. Lennon VA, Kryzer TJ, Pittock SJ, Verkman AS, Hinson SR. IgG marker of optic-spinal multiple sclerosis binds to the aquaporin-4 water channel. J Exp Med. 2005;202(4):473-7. http://doi.org/10.1084/jem.20050304

6. Wingerchuk DM, Lennon VA, Pittock SJ, Lucchinetti CF, Weinshenker BG et al. Revised diagnostic criteria for neuromyelitis optica. Neurology. 2006;66(10):1485-9. http://doi.org/10.1212/01.wnl.0000216139.44259.74

7. Wingerchuk DM, Lennon VA, Lucchinetti CF, Pittock SJ, Weinshenker BG The spectrum of neuromyelitis optica. Lancet Neurol. 2007;6(9):805-15. http://doi.org/10.1016/S1474-4422(07)70216-8

8. Wingerchuk DM, Banwell B, Bennett JL, Cabre P, Carroll W, Chitnis T et al. International consensus diagnostic criteria for neuromyelitis optica spectrum disorders. Neurology. 2015;85(2):177-89. http://doi.org/10.1212/WNL.0000000000001729

9. Jiao Y, Fryer JP, Lennon VA, Jenkins SM, Quek AM, Smith CY et al. Updated estimate of AQP4-IgG serostatus and disability outcome in neuromyelitis optica. Neurology. 2013;81(14):1197-204. http://doi.org/10.1212/WNL.0b013e3182a6cb5c

10. Kim W, Park MS, Lee SH, Kim SH, Jung IJ, Takahashi T et al. Characteristic brain magnetic resonance imaging abnormalities in central nervous system aquaporin-4 autoimmunity. Mult Scler. 2010;16(10):1229-36. http://doi.org/10.1177/1352458510376640

11. Lim YM, Pyun SY, Lim HT, Jeong IH, Kim KK. First-ever optic neuritis: distinguishing subsequent neuromyelitis optica from multiple sclerosis. Neurol Sci. 2014;35(5):781-3. http://doi.org/10.1007/s10072-014-1635-6

12. Cabre P, González-Quevedo A, Bonnan M, Saiz A, Olindo S, Graus F et al. Relapsing neuromyelitis optica: long term history and clinical predictors of death. J Neurol Neurosurg Psychiatry. 2009;80(10):1162-4. http://doi.org/10.1136/jnnp.2007.143529

13. Bizzoco E, Lolli F, Repice AM, Hakiki B, Falcini M, Barilaro A et al. Prevalence of neuromyelitis optica spectrum disorder and phenotype distribution. J Neurol. 2009;256(11):1891-8. http://doi.org/10.1007/s00415-009-5171-x

14. Collongues N, Marignier R, Zéphir H, Papeix C, Blanc F, Ritleng C et al. Neuromyelitis optica in France: a multicenter study of 125 patients. Neurol. 2010;74(9):736-42. http://doi.org/10.1212/WNL.0b013e3181d31e35

15. Cossburn M, Tackley G, Baker K, Ingram G, Burtonwood M, Malik G et al. The prevalence of neuromyelitis optica in south east Wales. Eur J Neur. 2012;19(4):655-9. http://doi.org/10.1111/j.1468-1331.2011.03529.x
16. Asgari N, Lillevang ST, Skejoe HP, Falah M, Stenager E, Kyvik KO. A population-based study of neuromyelitis optica in Caucasians. Neurology. 2011;76(18):1589-95. http://doi.org/10.1212/WNL.0b013e3182190f74

17. Jarius S, Ruprecht K, Wildemann B, Kuempfel T, Ringelstein M, Geis C et al. Contrasting disease patterns in seropositive and seronegative neuromyelitis optica: a multicentre study of 175 patients. J Neuroinflammation. 2012;9(1):14. http://doi.org/10.1186/1742-2094-9-14

18. Mealy MA, Wingerchuk DM, Greenberg BM, Levy M. Epidemiology of neuromyelitis optica in the United States: a multicenter analysis. Arch Neurol. 2012;69(9):1176-80. http://doi.org/10.1001/archneurol.2012.314

19. Papais-Alvarenga RM, Miranda-Santos CM, Puccioni-Sohler M, Almeida AM, Oliveira S, Oliveira CAB et al. Optic neuromyelitis syndrome in Brazilian patients. J Neurol Neurosurg Psychiatry. 2002;73(4):429-35. http://doi.org/10.1136/jnnp.73.4.429

20. Alves-Leon SV, Pimentel ML, Sant'anna G, Malfetano FR, Estrada CD, Quirico-Santos T. Immune system markers of neuroinflammation in patients with clinical diagnose of neuromyelitis optica. Arq Neuropsiquiatr. 2008;66(3B):678-84. http://doi.org/10.1590/S0004-282X2008000500013

21. Adoni T, Lino AM, Gama PD, Apóstolos-Pereira SL, Marchiori PE, Kok F et al. Recurrent neuromyelitis optica in Brazilian patients: clinical, immunological, and neuroimaging characteristics. Mult Scler. 2010;16(1):81-6. http://doi.org/10.1177/1352458509353651

22. Bichuetti DB, Oliveira EM, Souza NA, Rivero RL, Gabbai AA. Neuromyelitis optica in Brazil: a study on clinical and prognostic factors. Mult Scler. 2009;15(5):61-9. http://doi.org/10.1177/1352458508101935

23. Adoni T, Lino AM, Marchiori PE, Kok F, Callegaro D. Seroprevalence of NMO-IgG antibody in Brazilian patients with neuromyelitis optica. Arq Neuropsiquiatr. 2008;66(2B):295-7. http://doi.org/10.1590/S0004-282X2008000300001

24. Jarius S, Franciotta D, Paul F, Bergamaschi R, Rommer PS, Ruprecht $\mathrm{K}$ et al. Testing for antibodies to human aquaporin-4 by ELISA: sensitivity, specificity, and direct comparison with immunohistochemistry. J Neurol Sci. 2012;320(1-2):32-7. http://doi.org/10.1016/j.jns.2012.06.002

25. Waters PJ, McKeon A, Leite MI, Rajasekharan S, Lennon VA, Villalobos A et al. Serologic diagnosis of NMO: a multicenter comparison of aquaporin-4-lgG assays. Neurology. 2012;78(9):665-71. http://doi.org/10.1212/WNL.0b013e318248dec1

26. Isobe N, Yonekawa T, Matsushita T, Kawano Y, Masaki K, Yoshimura S et al. Quantitative assays for anti-aquaporin-4 antibody with subclass analysis in neuromyelitis optica. Mult Scler. 2012;18(11):1541-51. http://doi.org/10.1177/1352458512443917

27. Fryer JP, Lennon VA, Pittock SJ, Jenkins SM, Fallier-Becker P, Clardy SL et al. AQP4 autoantibody assay performance in clinical laboratory service. Neurol Neuroimmunol Neuroinflammation. 2014;11(1): e11. http://doi.org/10.1212/NXI.0000000000000011

28. Lana-Peixoto MA, Talim LE, Faria-Campos AC, Campos SV, Rocha CF, Hanke LA et al. NMO-DBr: The Brazilian Neuromyelitis Optica Database System. Arq Neuropsiquiatr. 2011;69(4):687-92. http://doi.org/10.1590/S0004-282X2011000500021 